\title{
Eksplorasi Ragam Nilai Karakter Bangsa Berbasis Kearifan Lokal Dalam Motif Batik Khas Banyuwangi
}

\author{
Reri Okta Primanata, Harjianto*, Moh. Sabiq Irwan H \\ Universitas PGRI Banyuwangi \\ Correspondence email: rerioktaprimanata@gmail.com, hr.bwin@gmail.com*, irwan.hariandi@gmail.com
}

\begin{abstract}
Abstrak. Kearifan lokal merupakan kerukunan beragaman dalam wujud praktik sosial yang dilandasi suatu kearifan dari budaya. Bentuk kearifan lokal dalam masyarakat dapat berupa budaya (nilai, norma, etika, kepercayaan, adat istiadat, hukum adat, dan aturan-aturan khusus. Motif batik yang tertuang pada batik Banyuwangi tidak hanya merupakan sebuah perwujudan estetika dari ragam hias namun juga memiliki nilai luhur yang dianut oleh mayarakat Banyuwangi. Tujuan penelitian ini adalah untuk mengetahui bagaimana filosofi motif batik khas Banyuwangi dan juga bagaimana keterkaitan motif batik khas Banyuwangi dengan nilai karakter bangsa.Metode penelitian yang digunakan dalam penelitian ini adalah kualitatif.Tempat penelitian yaitu sanggar batik virdes Desa Tampo Kecamatan Cluring Kabupaten Banyuwangi. Teknik analisis data yang digunakan adalah teknik analisis interaktif yang meliputi pengumpulan data, reduksi data, penyajian data, kemudian menarik suatu kesimpulan. Hasil dari penelitian ini adalah Motif batik gajah oling dapat membentuk karakter orang dilihat dari artinya yang mengajarkan tentang nilai kebaikan. Hal ini dapat dibuktikan pada setiap filosofi yang terdapat dalam setiap motif batik gajah oling, mulai dari motif corak daun kelapa melambangkan manusia harus seperti kelapa semuanya memiliki manfaat, corak daun melati melambangkan kita harus suci, bersih, dan tulus, motif daun dilem berasal dari sejenis tanaman semak yang dapat tumbuh dimana saja dan mempunyai khasiat sebagai obat-obatan, dan motif belalai gajah melambangkan kebesaran Tuhan Maha Kuasa, sehingga filosofi yang terdapat dalam motif gajah oling mencerminkan nilai-nilai Pancasila, karena secara hierarkis piramida Pancasila sila pertama Ketuhanan Yang Maha Esa menjiwai dari keempat sila Pancasila, yang artinya adalah manusia percaya dan taqwa terhadap Tuhan Yang Maha Esa sebagai pondasi keimanan dalam menjalani kehidupan sehari-hari.
\end{abstract}

Kata kunci: Eksporasi; Motif Batik Khas Banyuwangi; Nilai Karakter Bangsa.

\begin{abstract}
Local wisdom is diversity in the form of social practices which are based on wisdom from culture. The form of local wisdom in society can be in the form of culture (values, norms, ethics, beliefs, customs, customary laws, and special rules. The batik motifs embodied in Banyuwangi batik are not only an aesthetic manifestation of decorative styles but also have noble values. Banyuwangi community embraced. The purpose of this research is to find out how the philosophy of Banyuwangi's typical batik motifs and also how the relationship between Banyuwangi batik motifs and the national character values. The research method used in this research is qualitative. Cluring Banyuwangi Regency.The data analysis technique used is an interactive analysis technique which includes data collection, data reduction, data presentation, then drawing a conclusion. The result of this research is that the elephant oling batik motif can shape the character of the person seen from its meaning that teaches about the value of goodness. This can be proven in every philosophy contained in every oling elephant batik motif, starting from the coconut leaf motif symbolizing that humans must be like coconut everything has benefits, the jasmine leaf pattern symbolizes that we must be pure, clean, and sincere, the dilem leaf motif comes from a kind. bush plants that can grow anywhere and have medicinal properties, and the elephant's trunk motif symbolizes the greatness of God Almighty, so that the philosophy contained in the oling elephant motif reflects the values of Pancasila, because hierarchically the pyramid of Pancasila, the first precept of God Almighty animate the four principles of Pancasila, which means that humans believe and respect God Almighty as the foundation of faith in living their daily lives.
\end{abstract}

Keyword: Exploration; Banyuwangi Typical Batik Motifs; National Character Value

\section{PENDAHULUAN}

Indonesia merupakan negara yang berbentuk Republik, sebagai mana yang di atur dalam Pasal 1 ayat 1 UUD 1945. Indonesia dibagai atas provinsi-provinsi dan dibagi atas kabupaten dan kota, yang terdiri atas pulau-pulau, dan disebut dengan Nusantara, saat ini terdiri dari 33 provinsi. Kemajemukan suku, budaya, adat istiadat, dan bahasa merupakan ciri khas suatu bangsa, hal ini sejalan dengan pemikiran (Hans Kohn dalam Dwi Sulisworo dkk, 2012) Mengatakan bahwa bangsa adalah buah hasil hidup manusia dalam sejarah. Sejarah bangsa merupakan golongan yang beraneka ragam dan tidak bisa dirumuskan secara eksak. Faktor- faktor berupa persamaan keturunan, wilayah, bahasa, adat istiadat, kesamaan politik, perasaan dan agama merupakan faktor obyektif tertentu yang dimiliki dan membedakan dengan bangsa lain.

Bangsa Indonesia adalah bangsa yang memiliki ciri khas tersendiri yang membedakan dengan negara lain, baik dari budaya dan tradisi, masyarakatnya atau rakyat bangsanya. Implementasi tersebut tercermin dalam kehidupan sehari-hari sehingga menjadi karakter suatu bangsa. Karakter suatu bangsa sangat bergantung pada pemerintah, karena karakter suatu bangsa, selain sudah ada dari jaman dahulu merupakan visi dan misi suatu negara. 
Karakter utama suatu bangsa Indonesia yang tidak boleh digerogoti dengan cara apapun. Menurut (Hasyim Djalal, dalam Farida Hanun, 2009), yaitu: pertama,Indosesia sebagai suatu kebangsaan yang dicapai sejak Sumpah Pemuda 1928 yang menegaskan bahwa Indonesia adalah satu bangsa, satu tanah air, dan satu bahasa. Dengan demikian, bangsa Indonesia merupakan semua warga yang mendiami seluruh tanah air Indonesia, bukan memandang berdasarkan suku, agama, rasial ataupun mementingkan kelompokkelompok tertentu. Kedua, Indonesia adalah suatu bangsayang diproklamasikan tanggal 17 Agustus 1945. Bangsa Indonesia manyatakan dirinya hidup dalam suatu negara, yaitu Negara Kesatuan Republik Indonesia (NKRI). Karena itu tidak mungkin ada negara lain lagi di dalam NKRI tersebut. Ketiga, Indonesia adalah sutu kewilayahan, artinya bahwa Indonesia telah menjadi suatu bangsa yang berdiam di dalam suatu kesatuan kewilayahan, yaitu satu kesatuan nusantara yang mencakup wilayah darat, laut, udara, dan kekayaan alam.

Menurut (Wibisono dalam Diana Noor Anggraeni, 2001) karakter bangsa berisi nasionalisme dan rasa cinta pada tanah air. Mempertahankan eksistensiya sebagi bangsa kasatuan rasa dimiliki dan memiliki (sense of belongimg) dan mewujudkan suatu derajat nasionalisme.Oleh karena itu, bangsa Indonesia lebih baik ditinjau dari berbagai perspektif. Suatu bangsa akan berhasil menjalankan fungsi sebagai suatu bangsa jika setiap warga bangsa memiliki kesadaran bersama dalam membangun sebuah bangsa. Bahwa masyarakat membentuk suatu komunitas politik tertentu, di mana peranannya dibutuhkan oleh suatu warga bangsa.Dapat dikatakan bahwa dalam dinamika politik kehidupan bangsa harus terkandung nilai-nilai partisipasi dan akomodasi.Nasionalisme Indonesia merupakan perwujudan ikatan budaya yang menyatukan dan mengikat suku-suku yang ada di Indonesia menjadi satu bangsa dalam ikatan negara.

Perkembangan budaya di tengah era globalisai masyarakat semakin melupakan budaya/kearifan lokal.Keberadaan kearifan lokal merupakan hasil olah pikir yang panjang dan memiliki nilai-nilai leluhur yang ada didalamnya.Nilai-nilai luhur yang ada dalam kearifan lokal merupakan bukti konkrit, namun semakin lama budaya hanya digunakan sebagai suatu simbol atau arti tanpa memiliki makna yang penting lagi.Fakta tersebut membuat nilai kearifan lokal semakin terlupakan oleh generasi-generasi muda bangsa yang hanya mementingkan suatu perkembangan tanpa melihat nilai-nilai leluhur yang terkandung dalam kebudayaan maupun kearifan lokal.

Hakikatnya masyarakat Indonesia memiliki keanekaragaman tradisi, suku, dan latar belakang kearifan lokal yang berbeda.Kearifan lokal dari masingmasing daerah yang berada di Negara Indonsia sangatlah beragam.Salah satunya adalah kearifan lokal di Banyuwangi.Kearifan lokal di Banyuwangi merupakan warisan leluhur atau nenek moyang yang harus dilestarikan, sebab kearifan lokal secara tersirat merupakan identitas masing-masing daerah. Maka dari itu, diperlukan usaha dan kerja sama antara pemerintah ataupun masyarakat setempat dalam mengembangkan potensi dari kearifan lokal tersebut. Menurut (Keraf, 2002) mendefisinikan kearifan lokal sebagai suatu adat kebiasaan atau etika yang menuntun perilaku manusia dalam kehidupan di dalam komunitas serta bentuk pengetahuan, keyakinan, pemahaman, atau pengawasan. Menurut (Irwan Abdullah dkk, 2008) kearifan lokal didefinisikan sebagai kebenaran yang telah mentradisi atau objek dalam suatu daerah.Sedangkan menurut (Haryanto, 2014) menyatakan wujud budaya dalam kerukunan beragama merupkan bentuk kearifan lokal yang dilandasi dalam bentuk praktik soaial. Kearifan lokal dalam masyarakat dapat berupa budaya (nilai, norma, etika, kepercayaan, adat istiadat, hukum adat, dan aturan-aturan khusus). Nilai-nilai luhur kearifan lokal meliputi cinta kepada Tuhan, alam semesta beserta isinya.

Kearifan lokal yang masih terus dikembangkan oleh masyarakat di Banyuwangi salah satunya adalah batik.Batik sebagai bagian dari hasil seni budaya muncul dengan berbagai macam ragam hias dan motif sesuai dengan kondisi geografis, nilai sosial dan budaya, kepercayaan, adat istiadat, dan keadaan alam flora-fauna tiap daerah.Wilayah produsen batik di Banyuwangi yang masih berkembang hingga saat ini adalah sanggar batik Virdes yang terletak di Desa Tampo Kecamatan Cluring Kabupaten Banyuwangi.Sanggar Batik Virdes menghasilkan berbagai macam batik khas Banyuwangi, diantaranya yang dikenal sebagai batik gajah oling. Batik gajah oling menurut budayawan batik Banyuwangi merupakan motif batik asli Kabupaten Banyuwangi atau bisa dikatakan batik tertua dibanding motif batik yang ada di Banyuwangi.

Motif batik khas Kabupaten Banyuwangi yang seakan menyerupai huruf " $S$ " yang secara filosofi merupakan bentuk belalai gajah dan sekaligus digambarkan menyerupai uling (belut/moa) merupakan sebuah perwujudan estetika dari ragam hias namun juga memiliki nilai luhur yang dianut oleh masyarakat Banyuwangi. Kedua unsur tersebu membuat karakter gambar juga dikelilingi sejumlah atribut lain di antaranya daun dilem, Manggar ( bunga pinang/kelapa) dan sebainya.

Penelitian Mutiara Zehan (2012) yang berjudul Studi Desain dan motif Hias batik gajah oling Produksi Sanggar Batik Sayu Wiwit Banyuwangi. Batik gajah oling merupakan batik ciri khas daerah Banyuwangi, dan diproduksi oleh beberapa pengrajin batik di Banyuwangi. Salah satu industri kerajinan yang masih mempertahankan motif tradisional batik gajah oling adalah sanggar batik Sayu Wiwit. Sanggar Batik Sayu Wiwit masih tetap mempertahankan kriteria asli motif batik gajah oling yang terdiri dari ornamen gajah oling, 
ornamen daun dilem berjumlah tiga, ornamen bunga melati berkelopak lima, dan ornamen manggar berjumlah tiga.

Batik gajah oling merupakan Batik Khas Kabupaten Banyuwangi dan juga motif batik gajah oling yang terdiri dari ornamen gajah oling, ornamen daun dilem berjumlah tiga, ornamen bunga melati berkelopak lima dan ornamen Manggar berjumlah tiga. Batik osing merupakan khas Banyuwangi masih menggunakan cara tradisional dan juga masih mempertahankan kemurnian batik osing secara turun temurun.

Industri Batik di Kabupaten Banyuwangi hingga saat ini banyak tumbuh dan berkembang.Penghasil batik Banyuwangi menyebar hampir di seluruh wilayah Kabupaten Banyuwangi, hal ini terjadi dikarenakan adanya dukungan positif dari pemerintah Kabupaten Banyuwangi terhadap keberadaan Batik Banyuwangi. Kebijakan pemerintah daerah pengembangan batik di Banyuwangi serta pemanfaatan batik Banyuwangi untuk seragam dinas maupun sekolah, dan event-event tertentu. Melihat besarnya keinginan masyarakat akan batik saat ini, maka dari itu Pemerintah Daerah Kabupaten Banyuwangi meningkatkan pengembangan Batik Khas Banyuwangi mulai upaya pembinaan, pelatihan/bimbingan, teknik meningkatkan kualitas dan kuantitas produk, penerapan zat alam serta untuk menambah khasanah motif batik khas melalui pelaksanaan lomba desain batik khas banyuwangi.

\section{METODE}

Penelitian ini merupakan penelitian deskriptif kualitatif (Moleong, 2007), penelitian kualitatif adalah prosedur penelitian yang menghasilkan data yang berupa kata-kata tertukis atau lisan dari subjek/orang-orang dan perilaku yang dapat diamati.

Penelitian ini bertujuan untuk mendapat gambaran dan informasi yang lebih jelas, lengkap, serta memungkinkan dan mudah bagi peneliti untuk melakukan penelitian observasi. Oleh karena itu, maka penulis menetapkan lokasi penelitian adalah tempat di mana penelitian akan dilakukan. Dalam hal ini, lokasi penelitian terletak di Sanggar Batik Virdes Desa Tampo Kecamatan Cluring Kabupaten Banyuwangi.

Analisis data yang digunakan adalah metode deskriptif analitik, yaitu mendeskripsikan data yang dikumpulkan berupa kata-kata, gambar, dan bukan angka.Data yang berasal dari naskah, wawancara, catatan lapangan, dokumen, dan sebagainya, kemudian dideskripsikan sehingga dapat memberikan kejelasan terhadap kenyataan atau realitas

\section{HASIL DAN PEMBAHASAN}

Batik merupakan suatu bentuk budaya yang tak lepas dari adanya upaya pewarisan, baik dalam hal keterampilan membatik dan nilai sosial budaya yang terkandung di dalamnya.Batik merupakan seni budaya yang digunakan oleh Indonesia sebagai identitas
bangsa.Perusahaan yang sampai saat ini masih tetap mempertahankan batik di Kabupaten Bayuwangi salah satunya perusahaan Batik Virdes.

Perusahaan batik virdes adalah perusahaan swasta dengan jenis usaha industri kerajinan batik dan garmen. Produk batik terdiri dari batik tulis dan batik cap yang mempunyai ciri khas tersendiri. awal terbentuk perusahaan yang didirikan oleh Bapak Moch. Suyadi di kediamannya dan dikelola dengan keluarga dan saudaranya di Banyuwangi. beliau sebelumnya bekerja pada perusahaan batik yang ada di Bali selama 13 tahun lamanya, untuk mencari modal agar bisa membuka usaha sendiri di Banyuwangi. pengalaman dan relasi kerja yang didapat selama di Bali, Kemudian beliau mulai merintis usahanya bersama pengrajin batik yang ada di sekitar daerah rumah dan rekan kerjanya di Bali, berawal pada kecintaan seni dan budaya yang ada di Banyuwangi.

Perusaan berdiri pada tanggal 3 November 1986 dan terus berkembang dan berkarya sampai sekarang. penghargaan dan kegiatan keterampilan sudah banyak diikuti serta diberikan kepada perusahaan ini. tempat produksi berada di areal rumah bapak Suryadi yang berada dengan galeri shop nya berada ada di pusat kota, dengan ijin usaha No 510/918/429.310 SIUP.M/2006 dan No Merk Agno D00-02-00041 yang sudah dilabelkan oleh pemerintah Kabupaten Banyuwangi sebagai bukti bahwa kelayakan dan eksistensi usaha industri yang sudah mempunyai ijin. Tempat usaha yang didirikan bukan hanya tempat produksi saja tapi tempat kediaman Bapak saya di dan keluarganya, musholla, penginapan tamu dari luar kota, perpustakaan tentang batik serta karya ilmiah penelitian di perusahaan batik virdes. Bapak Suryadi juga merencanakan tempat untuk pembuatan museum batik di sekitar tempat produksi dan itu masih dalam tahap proses melalui pemerintah, keinginan tersebut dimaksudkan untuk tempat pelestarian batik Banyuwangi.

Banyuwangi memiliki potensi yang sangat baik dalam pengembangan batiknya, sebagai contoh Sanggar batik Virdes yang menggunakan Bunga sepatu yang ada disekitar Sanggar sebagai motif dari pengembangan batik gajah oling. Hal ini sangatlah berkesan karena tidak semua pembatik memiliki pemkiran atau ide yang sama, sehingga dapat menjadi sebuah pembeda atau juga sebuah cirikhas tersendiri dari setiap Sanggar Batik. Sanggar batik virdes menggunakan 2 (dua) cara untuk membuat batik. Batik tulis proses pembuatannya menggunakan canting dan proses pembuatan batik cap alat yang digunakan yaitu cap (semacam stempel besar yang terbuat dari tembaga)

Batik gajah oling diyakini oleh beberapa budayawan dan pemerhati batik, dan masyarakat Banyuwangi bahwa gajah oling merupakan motif batik khas Banyuwangi yang asli atau bisa dikatakan tertua dibandingkan motif batik yang ada di Banyuwangi 
Sejarah batik gajah oling berkembang sejak abad ke16-17 Masehi.Pada (1613-1645 M) merupakan masa penaklukan Blambangan oleh Mataram yakni pada masa Sultan Agung Hanyorko Kusumo.Pada kekuasaan Mataram banyak pemuda-pemudi Blambangan dibawa ke pusat Pemerintahan Mataran Islam.Pemuda-pemudi Blambangan ini belajar membatik di Keraton Mataram Islam.Dari beberapa pendapat masyarakat masa kini tentang arti dari gajah ling ini adalah oling yang berarti binatang sejenis belut, dan gajah tidak digambarkan sebagaimana bentuk binatang melainkan melambangkan bentuk yang besar, sehingga bisa dikatakan gajah oling adalah hewan oling yang besar (Baihaqi, 2008).

Filosofi gajah oling yang merupakan plesetan dari Gajah Eling yang memiliki arti sosok yang besar Gajah (dilambangkan dengan belalai gajah) dan kata Eling yang akhirnya menjadi oling.Penciptaan pertama gajah oling memberi makna, filosofi yang berarti bahwa mengingatkan Tuhan Yang Maha Besar adalah sebuah jalan terbaik dalam menjalani hidup ini.Motif batik gajah oling terdiri dari gambar yang seakan menyerupai huruf "S", yang memiliki filosofi bentuk sebuah belalai gajah dan sekaligus digambarkan menyerupai uling (seekor belut besar).

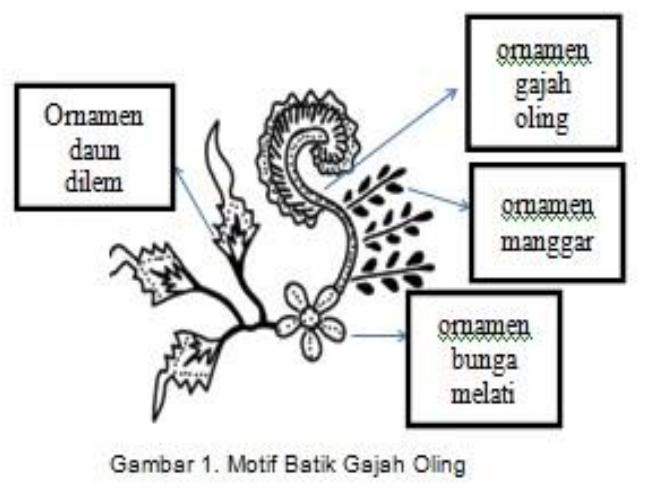

Batik Gajah Oling juga memiliki ornamen bunga kelapa (manggar), melambangkan manusia harus seperti kelapa semuanya memiliki manfaat.Ornamenbunga melati, melambangkan bunga melati yang warnanya putih dan harum jadi esensinya kita harus suci, bersih, dan tulus.Ornamen daun dilem berasal dari sejenis tanaman semak yang dapat tumbuh dimana saja dan mempunyai khasiat sebagai obat-obatan, artinya jadilah manusia yang bermanfaat.

Karakter Bangsa digunakan sebagai pedoman dalam merubah prilaku manusia, nilai-nilai yang digunakan sebagai tolak ukur terdapat pada Piramida Pancasila Yang dijelaskan sebagai berikut: Sila pertama: ketuhanan yang maha esa meliputi dan menjiwai sila sila kemanusiaan yang adil dan beradab, persatuan Indonesia, kerakyatan yang dipimpin oleh hikmat kebikjaksaan dalam permusyawaratan/ perwakilan serta keadilan sosial bagi seluruh rakyat indonesia.
Sila kedua: kemanusiaan yang adil dan beradab diliputi dan dijiwai oleh sila Ketuhanan Yang Maha Esa, meliputi dan menjiwai sila persatuan Indonesia, kerakyatan yang dipimpin oleh hikmat kebijaksanaan dalam permusyawaratan/ perwakilan serta keadilan sosial bagi seluruh seluruh rakyat Indonesia.

Sila ketiga: persatuan Indonesia diliputi dan dijiwai sila Ketuhanan Yang Maha Esa, kemanusiaan yang adil dan beradab meliputi dan menjiwai sila kerakyatan yang dipimpin oleh hikmat kebijaksanaan dalam permusyawaratan/ perwakilan serta keadilan sosial bagi seluruh rakyat Indonesia.

Sila keempat : kerakyatan yang dipimpin oleh hikmat kebijaksanaan dalam permusyawaratan perwakilan diliputi dan dijiwai oleh sila Ketuhanan yang maha esa, kemanusiaan yang adil dan beradab, persatuan Indonesia, serta meliputi dan menjiwai Sila keadilan sosial bagi seluruh rakyat Indonesia.

Sila kelima : keadilan sosial bagi seluruh rakyat Indonesia lirik putih dan dijiwai oleh sila ketuhanan yang maha esa, kemanusiaan yang adil dan beradab, persatuan Indonesia kerakyatan yang dipimpin oleh hikmat kebijaksanaan dalam permusyawaratan/ perwakilan, serta keadilan sosial bagi seluruh rakyat Indonesia.

Manusia sebagai pendukung pokok sila-sila Pancasila secara ontologis memiliki hal-hal yang mutlak, yaitu terdiri atas susunan kodrat raga dan jiwa, jasmani dan rohani, sifat kodrat manusia adalah sebagai mahluk individu dan mahluk sosial, serta kedudukan kodrat manusia sebagai mahluk Tuhan Yang Maha Esa. Maka secara hierarkis sila pertama Ketuhanan Yang Maha Esa mendasari dan menjiwai keempat sila-sila Pancasila yang lain, artinya bahwa dalam pendidikan karakter nilai religius yang diutamakan dalam mengubah karakter manusia. Karena Ketuhanan Yang Maha Esa merupakan nilai keimanan setiap manusia dalam menjalani kehidupan sehari-hari.

Berdasarkan penjelasan di atas Pancasila dapat membentuk karakter bangsa, karena pembentukan karakter seseorang dimulai dari pemahaman terhadap nilai-nilai kebaikan.filosofi yang terdapat pada motif batik gajah oling dapat dikatakan bahwa motif batik gajah oling dapat membentuk karakter orang dilihat dari artinya yang mengajarkan tentang nilai kebaikan. Hal ini dapat dibuktikan pada setiap filosofi yang terdapat dalam setiap motif batik gajah oling artinya perputaran yang mengarah kepada ketuhanan, mulai dari motif corak daun kelapa, corak daun melati, motif daun dilem, motif belalai gajah mencerminkan nilai-nilai Pancasila, yang artinya adalah manusia percaya dan taqwa terhadap Tuhan Yang Maha Esa, sesuai dengan agama dan kepercayaannya masing-masing menurut dasar kemanusiaan yang adil dan beradap, sehingga manusia memiliki rasa toleransi, saling menghargai dan memiliki rasa gotong royong (saling membantu) 


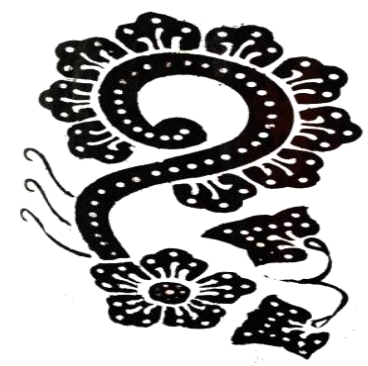

Gambar 2. Motif Batik Gajah Oling Memilki Lambang Tanda Tanya (“?”)

Filosofi batik gajah oling berkaitan erat dengan nilai pendidikan karakter yang lebih mengutamakan nilai religius, nilai religius yang berarti bahwa setiap perbuatan manusia didasari oleh nilai keimanan masingmasing orang, karena keimanan yang manusia miliki akan membawa perbuatan-perbuatan baik lainnya. Sebaliknya apabila iman manusia tidak baik maka perbuatan-perbuatan buruk pasti akan dilakukan. Hal ini mencerminkan bahwa, keimanan sebagai nilai religius sangan penting sebagai pedoman kehidupan bermasyarakat

Filosofi batik gajah oling yang berarti menginggat Allah Yang Maha Besar merupakan nilai karakter bangsa yang terdapat pada Pancasila, sedangkan apabila dikaji dari motif batik gajah oling Karakter Bangsa Indonesia adalah ciri khas dan sikap suatu bangsa yang tercermin pada tingkah laku dan pribadi warga suatu negara. Sikap tersebut dapat dipengaruhi oleh sesuatu yang yang sudah ada dan dapat diusahakan negara/pemerintah demi kemajuan bangsanya.Oleh sebab itu, karakter bangsa sangat bergantung pemerintah atau para penguasa suatu negara, sebab karakter bangsa, selain sudah ada dari awalnya juga merupakan olah pikir yang dibangun sesuai dengan visi dan misi suatu negara.

Sejarah telah membuktikan bahwa para tokohtokoh bangsa Indonesia telah meletakkan pondasi dan dasar negara yang menjadi karakter sebuah bangsa, yang penting untuk dikembangkan dan ditransformasikan agar menjadi milik seluruh warga bangsa negara Indonesia. Ada tiga tiang utama jati diri bangsa Indonesia yang tidak boleh digerogoti dengan cara apapun (Hasyim Djalal, dalam Farida Hanun, 2009), yaitu: Pertama, Indonesia sebagai suatu kebangsaan. Hal ini dicapai sejak Sumpah Pemuda 1928 yang menegaskan bahwa Indonesia adalah satu bangsa, satu tanah air, dan satu bahasa. Dengan demikian, bangsa Indonesia bukanlah berdasarkan suku, agama, rasial ataupun mementingkan kelompok-kelompok tertentu, tetapi adalah semua warga yang mendiami seluruh tanah air Indonesia. Kedua, Indonesia adalah suatu negara yang diproklamasikan tanggal 17 Agustus 1945.Ini berarti bahwa manusiamanusia Indonesia menyatakan dirinya hidup dalam satu negara, yaitu Negara Kesatuan Republik Indonesia (NKRI).Karena itu tidak mungkin ada negara lagi di dalam NKRI tersebut.Ketiga, Indonesia adalah satu kewilayahan, dalam arti bahwa orang- orang Indonesia yang telah menjadi suatu bangsa itu, berdiam di dalam satu kesatuan kewilayahan, yaitu satu kesatuan nusantara Indonesia yang mencakup wilayah darat, laut, udara, dan kekayaan alam

Berdasarkan arti dari nama batik gajah oling maka dapat dijelaskan pada sila pertama, Ketuhanan Yang Maha Esa mengartinya bahwa Tuhan itu satu (Esa), sehingga dalam filosofi motif batik gajah oling yang artinya Allah (Tuhan) Yang Maha Besar melambangkan bahwa terdapat toleransi dan kearmonisan antar umat beragama, karena masyarakat Banyuwangi memiliki keyakinan yang berbeda-beda, seperti Islam, Hindu, Budha, Keristen, Katolik dan Tionghoa. Dari beberapa agama yang dianut filosofi batik gajah oling mengingatkan bahwa Tuhan adalah Maha Besar dan tidak ada kebesaran lain selain milik Tuhan.

Sila kedua, kemanusian yang adil dan beradap bahwa hakikat manusia adalah susunan kodrat jasmani dan rohani, kodrat sebagai makhluk individu dan sosial, kedudukan kodrat sebagai makhluk pribadi makhluk Tuhan yang Maha Esa. Sila ketiga, persatuan Indonesia terkandung makna bahwa negara merupakan persekutuan hidup bersama di antara elemen-elemen yang membentuk negara yang berupa suku, ras, kelompok, golongan, maupun agama. Sila Keempat, Kerakyatan yang Dipimpin Oleh Hikmat Kebijaksanaan dalam permusyawaratan Perwakilan. Nilai filosofis yang terkandung dalam sila Kerakyatan yang dipimpin oleh hikmat kebijaksanaan dalam permusyawaratan/ perwakilan, bahwa rakyat adalah merupakan sekelompok manusia sebagai makhluk Tuhan Yang Maha Esa Yang bersatu yang bertujuan mewujudkan harkat dan martabat manusia dalam suatu wilayah negara. Sila Kelima, Keadilan Sosial bagi Seluruh Rakyat Indonesia. Pada sila kelima ini terkandung nilai keadilan yang harus terwujud dalam kehidupan sosial (kehidupan bersama)' Hakikat keadilan sosial adalah keadilan dalam hubungan manusia dengan dirinya sendiri, dengan manusia lain, masyarakat bangsa dan negara, serta dengan Tuhannya.Pada dasarnya filosofi batik gajah oling terdiri dari dua suku kata pertama gajah atau besar dan kedua oling yang diambil dari bahasa jawa yaitu Eling sehingga jika diartinya selalu ingat kebesaran Tuhan dan menginggat kebesaran Tuhan adalah jalan terbaik untuk menjalani hidup ini.

Motif pada kain batik gajah oling memiliki esensi yang begitu dalam dan tiap corak memiliki makna tersendiri.Corak bunga kelapa, melambangkan manusia harus seperti kelapa semuanya memiliki manfaat. Pada sila ke 2 Kemanusiaan yang Adil dan Beradab, artinya menempatkan manusia sesuai dengan hakikatnya sebagai makhluk Tuhan yang, harus saling menghargai, tolongmenolong dan bekerjasama dan Menghargai perbedaan dan menjaga keharmonisan dalam kehidupan bersama.

Motif Corak bunga melati, melambangkan bunga melati yang warnanya putih dan harum jadi esensinya 
kita harus suci, bersih, dan tulus. Kebaikan itu akan terpancar ke luar bila dilakukan dengan tulus. Motif corak bunga melati tercerminkan pada sila ke 1 Ketuhanan Yang Maha Esa, dimana hakikatnya setiap orang memeluk keyakinan masing-masing, bagaimana kita menjalani sebuah hidup dengan keharmonisan dalam beragama, saling mengahargai, menghormati, dan toleransi terhadap sesama manusia sehingga dibutuhkan rasa ketulusan yang tertuang dalam motif corak bunga melati.

Pada daun dilem berasal dari sejenis tanaman semak yang dapat tumbuh dimana saja dan mempunyai khasiat sebagai obat-obatan, artinya jadilah manusia yang bermnfaat, hal ini mencerminkan nilai dari sila ke 1, ke 2 dan ke 5. Ketiga sila Pancasila memberikan arti bahwa, manusia harus memiliki sebuah keyakinan sebagai penuntun hidup untuk menjadi menusia yang lebih baik, menusia sebagai mahluk ciptaan Allah SWT dihadapan-Nya adalah sempurna dan tidak ada bedanya sehingga dikatakan bahwa manusia adalah mahluk yang paling sempurna, dan manusia memiliki sebuah keadilan yang sama sehingga muncul sebuah aturan/norma yang bertujuan untuk menjadi menusia menjadi lebih baik dan menciptakan ketertiban dalam hidup setiap manusia. Sedangkan bentuk belalai gajah yang lingkarannya berlawanan dengan jarum jam artinya perputaran yang mengarah kepada ketuhanan. Motif batik ini lebih mencerminkan bahwa manusia adalah ciptaan-Nya dan meyakini bahwa Tuhan itu ada.Hal ini tercerminkan pada sila-sila Pancasila yang menjadi dasar hidup bernegara dan berbangsa.

Manusia sebagai pendukung pokok sila-sila Pancasila secara ontologis memiliki hal-hal yang mutlak, yaitu terdiri atas susunan kodrat raga dan jiwa, jasmani dan rohani, sifat kodrat manusia adalah sebagai mahluk individu dan mahluk sosial, serta kedudukan kodrat manusia sebagai mahluk Tuhan Yang Maha Esa. Maka secara hierarkis sila pertama Ketuhanan Yang Maha Esa mendasari dan menjiwai keempat sila-sila Pancasila yang lain, artinya bahwa dalam pendidikan karakter nilai religius yang diutamakan dalam mengubah karakter manusia. Karena Ketuhanan Yang Maha Esa merupakan nilai keimanan setiap manusia dalam menjalani kehidupan sehari-hari.

Berdasarkan penjelasan di atas Pancasila dapat membentuk karakter bangsa, karena pembentukan karakter seseorang dimulai dari pemahaman terhadap nilai-nilai kebaikan.filosofi yang terdapat pada motif batik gajah oling dapat dikatakan bahwa motif batik gajah oling dapat membentuk karakter orang dilihat dari artinya yang mengajarkan tentang nilai kebaikan. Hal ini dapat dibuktikan pada setiap filosofi yang terdapat dalam setiap motif batik gajah oling artinya perputaran yang mengarah kepada ketuhanan, mulai dari motif corak daun kelapa, corak daun melati, motif daun dilem, motif belalai gajah mencerminkan nilai-nilai Pancasila, yang artinya adalah manusia percaya dan taqwa terhadap
Tuhan Yang Maha Esa, sesuai dengan agama dan kepercayaannya masing-masing menurut dasar kemanusiaan yang adil dan beradap, sehingga manusia memiliki rasa toleransi, saling menghargai dan memiliki rasa gotong royong (saling membantu)

\section{SIMPULAN}

Motif batik gajah oling dapat membentuk karakter orang dilihat dari artinya yang mengajarkan tentang nilai kebaikan. Hal ini dapat dibuktikan pada setiap filosofi yang terdapat dalam setiap motif batik gajah oling, mulai dari motif corak daun kelapa melambangkan manusia harus seperti kelapa semuanya memiliki manfaat, corak daun melati melambangkan kita harus suci, bersih, dan tulus, motif daun dilem berasal dari sejenis tanaman semak yang dapat tumbuh dimana saja dan mempunyai khasiat sebagai obat-obatan, dan motif belalai gajah melambangkan kebesaran Tuhan Maha Kuasa, sehingga filosofi yang terdapat dalam motif gajah oling mencerminkan nilai-nilai Pancasila, karena secara hierarkis piramida Pancasila sila pertama Ketuhanan Yang Maha Esa menjiwai dari keempat sila Pancasila, yang artinya adalah manusia percaya dan taqwa terhadap Tuhan Yang Maha Esa sebagai pondasi keimanan dalam menjalani kehidupan sehari-hari

\section{DAFTAR PUSTAKA}

Abdullah, Irwan dkk, 2008, Agama dan Kearifan Lokal dalam Tantangan Global, Yogyakarta :Sekolah Pascasarjana UGM dan Pustaka Belajar

Baihaqi, Agus (2008). 'Bekreasi Tanpa Meninggalkan Motif Banyuwangi". Jawa Pos

Diana A Noor, 2015, Pengaruh Penerapan Materi Education For Sustanable Development (EDS) dalam Bahan Ajar PPKN terhadap Peningkatan Civic Disposition Siswa, Universitas Pendidikan Indonesia.

Hanum Farida, 2009, Pendidikan Multikultural sebagai Sarana Pembentuk Karakter Bangsa (Dalam Perspektif Sosiologi Pendidikan), Seminar Regional DIY-Jateng. Universitas Negeri Yogyakarta

Hariyanto, 2014, Asessmen Pendidikan, Bandung : PT. Remaja Rosdakarya

Keraff, 2009, Prosiding Seminar Nasional Penelitian, Pendidikan dan Penerapan MIPA, Fakultas MIPA, Universitas Negeri Yogyakarta

Mutiara Zehan dkk, 2012, Studi Desai dan Motif Batif Hias Batik Gajah Oling Produksi Sanggar Batik Sayu Wiwit Banyuwangi, Universitas Negeri Malang.

Moleong, Lexy J, 2007, Metodologi Penelitian Kualitatif, Bandung : PT. Remaja Rosdakarya

Sulisworo, Dwi, dkk, 2012, Pancasila sebagai Sistem Filsafat dan Impikasinya, Universitas Ahmad Dahlan 
Reri Okta Primanata, Harjianto dan Moh. Sabiq Irwan H, Eksplorasi Ragam Nilai Karakter Bangsa Berbasis Kearifan Lokal Dalam Motif Batik Khas Banyuwangi

Sugiyono, 2013, Metode Penelitian Pendidikan Pendekatan Kuantitatif, Kualitatif dan $R \& D$. Bandung : Alfabeta.

Suhady, Idup, 2003, Wawasan Kebangsaan dalam Kerangkan Negara Kesatuan Republik Indonesia, Jakarta: Lembaga Administrasi Negara. 